\title{
Late Holocene palynology and palaeovegetation of tephra-bearing mires at Papamoa and Waihi Beach, western Bay of Plenty, North Island, New Zealand
}

\author{
R. M. Newnham,* D. J. Lowe ${ }^{\dagger}$, G. N. A. Wigley ${ }^{\dagger \#}$
}

\begin{abstract}
The vegetation history of two mires associated with Holocene dunes near the western Bay of Plenty coast, North Island, New Zealand, is deduced from pollen analysis of two cores. Correlation of airfall tephra layers in the peats, and radiocarbon dates, indicate that the mires at Papamoa and Waihi Beach are c. 4600 and c. 2900 conventional radiocarbon years old, respectively. Tephras used to constrain the chronology of the pollen record include Rotomahana (1886 AD), Kaharoa (700 yr B.P.), Taupo (Unit Y; 1850 yr B.P.), Whakaipo (Unit V; 2700 yr B.P.), Stent (Unit Q; 4000 yr B.P.), Hinemaiaia (Unit K; 4600 yr B.P.), and reworked Whakatane (c. 4800 yr B.P.) at Papamoa, and Kaharoa and Taupo at Waihi Beach. Peat accumulation rates at Papamoa from $4600-1850 \mathrm{yr}$ B.P. range from 0.94 to $2.64 \mathrm{~mm} / \mathrm{yr}$ (mean $1.37 \mathrm{~mm} / \mathrm{yr}$ ). At Waihi Beach, from $2900 \mathrm{yr}$ B.P. - present day, they range from 0.11 to $0.21 \mathrm{~mm} / \mathrm{yr}$ (mean $0.20 \mathrm{~mm} / \mathrm{yr}$ ). Peat accumulation at both sites was slowest from 1850 to $700 \mathrm{yr}$ B.P., suggesting a drier overall climate during this interval.

At both sites, the earliest organic sediments, which are underlain by marine or estuarine sands, yield pollen spectra indicating salt marsh or estuarine environments. Coastal vegetation communities declined at both sites, as sea level gradually fell or the coast prograded, and were eventually superseded by a low moor bog at Papamoa, and a mesotrophic swamp forest at Waihi Beach. These differences, and the marked variation in peat accumulation rates, probably reflect local hydrology and are unlikely to have been climatically controlled. The main regional vegetation during this period was mixed northern conifer-angiosperm forest. Kauri (Agathis australis) formed a minor component of these forests, but populations of this tree have apparently not expanded during the late Holocene at these sites, which are near its present southern limit. Occasional shortlived forest disturbances are detectable in these records, in particular immediately following the deposition of Taupo Tephra. However, evidence for forest clearance during the human era is blurred by the downward dislocation of modern adventive pollen at these sites, preventing the clear differentiation of the Polynesian and European eras.
\end{abstract}

Keywords: palynology, late Holocene, vegetation history, climate change, tephrochronology, peat, Papamoa Bog, Waihi Beach Swamp

\section{INTRODUCTION}

A belt of coastal sand dunes, aligned parallel to the coast, stretches from Waihi Beach in the northwest to eastern Bay of Plenty (Fig. 1). Inland from this narrow coastal strip are lowlying (2-6 m a.s.1) drained swamplands, peatlands, tidal flats, river terraces, and floodplains, all formed since Holocene sea level reached approximately its present position c. 6500 years

\footnotetext{
*Department of Geographical Sciences, University of Plymouth, Plymouth, Devon PL4 8AA, England $\dagger$ Department of Earth Sciences and Geochronology Research Unit, University of Waikato, Private Bag 3105, Hamilton, New Zealand

\# Present address: C. L. Associates, Prospect House, Prospect Road, Mucklow Hill, Halesowen, Birmingham B62 8DU, England
} 
ago (Wigley 1990). At numerous sites along this coastline, a number of thin tephra layers are found within peat in bogs or in swales between dunes, while the organic sediments preserve records of the past vegetation and environmental history of the area. A chronology of development of the dunes at Papamoa Beach, western Bay of Plenty (Fig. 1), has been established (Lowe et al. 1992), similar to that described for the Rangitaiki Plains, eastern Bay of Plenty, by Pullar \& Selby (1971).

Campbell et al. (1973) described the vegetation history at three peat sites along the coastal Bay of Plenty strip, based on plant macrofossils and pollen. The peat is mainly a low-moor, sedge peat formed from Baumea (Cyperaceae). They concluded that in wetter periods Restionanceae (mostly Empodisma minus) became established, and in drier periods, Leptospermum and Gleichenia.

In this study, we present palynological evidence for the development of coastal mire vegetation communities at Papamoa Bog and Waihi Beach, from tephra-bearing organic sediments overlying sands at both sites. An understanding of the origins and evolution of these features of the western Bay of Plenty coastline is important because the sites are likely to become less accessible, or to be destroyed, by expanding urban development. The dryland pollen assemblages also provide evidence for the regional vegetation history of western Bay of Plenty since c. 4600 years ago, with chronologies at both sites determined from tephrochronology and radiocarbon dating.

\section{The physical setting, modern vegetation, and location of coring sites}

\section{Papamoa Bog}

Papamoa Bog (also known as Kaituna swamp) is a mesotrophic mire, $35.4 \mathrm{~km}^{2}$ in area and with a maximum elevation of $7.5 \mathrm{~m}$ a.s.1. (Davoren 1978), near Papamoa (Fig. 1). Currently up to $4.5 \mathrm{~m}$ deep, the bog is bounded largely by Holocene coastal dunes and low-lying fluvial terraces (Wigley 1990). Extensive drainage, particularly since implementation of the Kaituna River Catchment Scheme in the 1950s, has caused shrinkage of the bog's surface by up to $2 \mathrm{~m}$ in places (Pullar 1970); the surface gently undulates because of subsidence and exhumation of old stumps (probably Laurelia novae-zelandiae, Dacrycarpus dacrydioides, or Prumnopitys taxifolia: Pullar \& Patel 1972; Davoren 1978). The bog has been developed for agriculture and is today mostly covered in pasture grasses with patches of rushes (Juncus spp.) and occasional blackberry (Rubus fruticosus agg.), cabbage tree (Cordyline australis), and willow (Salix cinerea) (Davoren 1978).

Mean annual rainfall at nearby Te Puke is $1680 \mathrm{~mm}$; mean daily temperature is $13.9^{\circ} \mathrm{C}$ (Quayle 1984).

The core (code Kt16-b) was taken from around the deepest part of the bog on 2 July, 1991, using a D-section 'Russian' corer at site Kt16 (Fig. 1B). This site is c. $10 \mathrm{~m}$ or so from a site cored previously by Wigley (1990) (code Kt16-a).

\section{Waihi Beach Swamp}

Waihi Beach Swamp occupies a depression adjacent to low-lying fluvial terraces on the inland margins of Holocene coastal dunes at Waihi Beach (Fig. 1). The swamp has an area of c. $0.5 \mathrm{~km}^{2}$ and lies at c. 5-10 m elevation a.s.l.; a small, sluggish stream partly drains it (Fig. 1A). The peaty sediments in the swamp are everywhere likely to be $<1 \mathrm{~m}$ deep.

The modern vegetation comprises three main assemblages (P.J. de Lange pers. comm. 1994): (1) grey or pussy willow car (Salix cinerea) with manuka (Leptospermum scoparium); (2) rushland dominated by Juncus gregiflorus with J. effusus, J. australis, and J. articulatus, and occasional Carex virgata and $C$. secta; and (3) marginal rough pasture likely to be dominated by creeping bent (Agrostis stolonifera), yorkshire fog (Holcus lanatus), and floating sweet grass (Gylceria fluitans) with articulated rush (Juncus articulatus). Such assemblages are typical of mesotrophic mires (bordering on eutrophic).

Mean annual rainfall at Waihi Beach is $1620 \mathrm{~mm}$; the mean daily temperature at nearby Waihi is c. $13.7^{\circ} \mathrm{C}$ (Quayle 1984). 


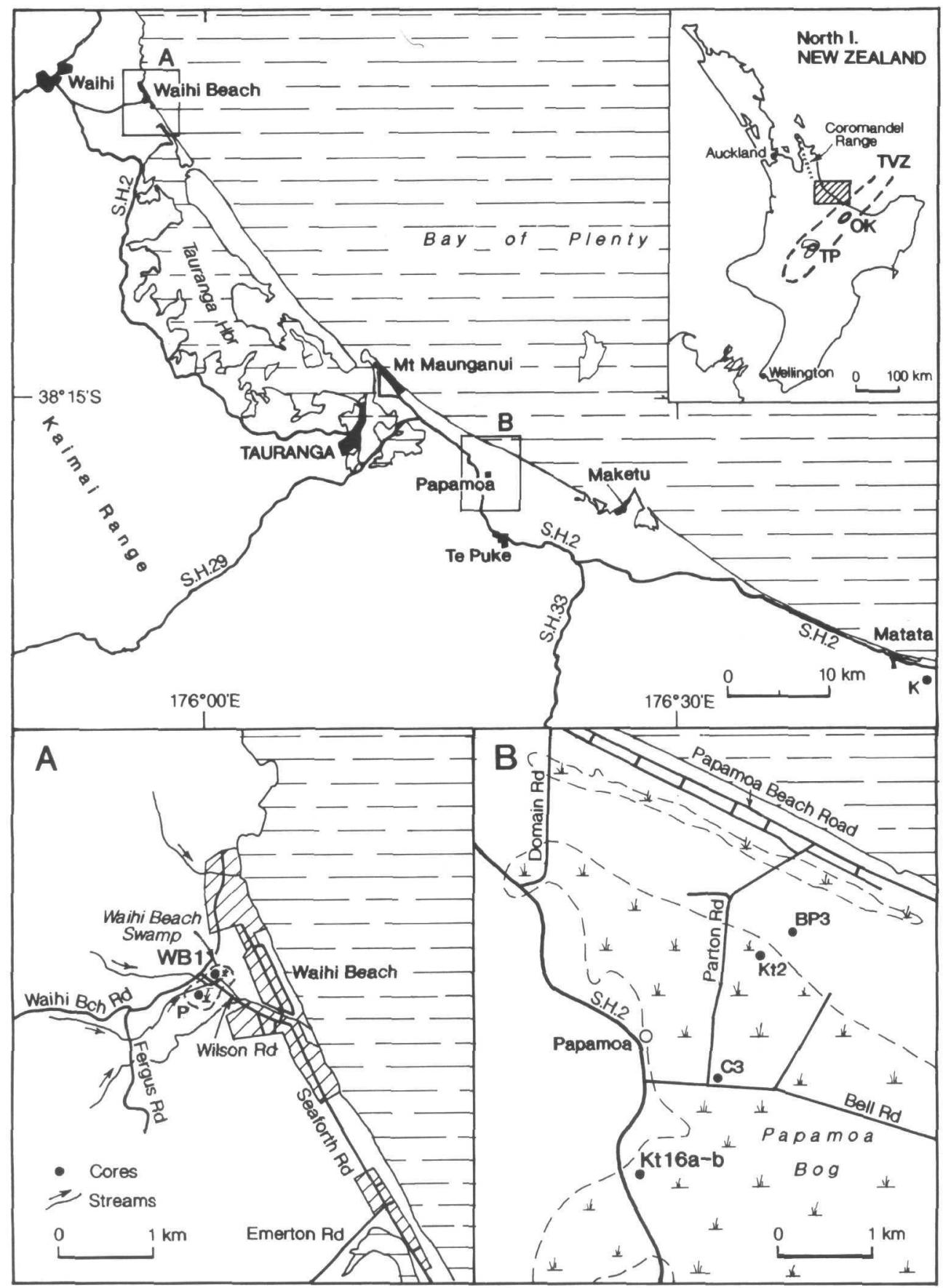

Fig. 1 - The western Bay of Plenty region showing locations of the Waihi Beach (WB1) and Papamoa (Kt16a-b) coring sites. Other core sites mentioned in the text are shown also: K, (Kohika swamp, McGlone 1981); P, Pullar et al. (1977); C3, Campbell et al. (1973); BP3, Alloway et al. (1994); Kt2, Wigley (1990). Inset shows locations of the Okataina (OK) and Taupo (TP) volcanic centres (Froggatt \& Lowe 1990). 
The core (code WB1) was taken from a patch of willow car with a D-section 'Russian' corer on 3 July, 1991 (Fig. 1A).

\section{STRATIGRAPHY AND CHRONOLOGY OF THE CORES}

\section{Papamoa Bog}

The stratigraphy of the core used for pollen analysis, Ktl6-b, is virtually identical to that of core Kt16-a (Fig. 2A). Both cores are underlain by fine sands or silts, with occasional cockle shells (Chione stutchburyi), of estuarine origin. Elsewhere in Papamoa Bog (core Kt-2, Fig. 1B) such shells have been dated at $(\mathrm{Wk}-1440) 5888 \pm 160 \mathrm{yr}$ B.P.* (corrected for the marine reservoir effect). Overlying these basal sediments are peat deposits, up to $4.4 \mathrm{~m}$ thick, interspersed with tephra layers. The peat colour ranges from black to brown and, apart from the upper metre or so which is fibrous, is strongly decomposed. Woody fragments occur throughout the cores (Fig. 2A).

\section{Tephrochronology}

Most of the tephra deposits form macroscopic layers 1 to $5 \mathrm{~cm}$ thick that range from fine ash to lapilli in grade. One layer (Stent), found as a gritty, disseminated deposit in core Kt 16-b, is well represented as a macroscopic layer in the equivalent stratigraphic position in core Ktl6a (Fig. 2A). Six tephras are identified in the peat columns, as shown in Fig. 2A. All are derived from either Okataina or Taupo volcanic centres (Fig. 1, inset). Correlations with named deposits elsewhere are based on a combination of stratigraphic position, field properties, radiocarbon age, ferromagnesian mineralogical assemblage, and major element composition of glass (e.g., see Lowe 1988a, b).

Rotomahana Mud (a member of Tarawera Tephra; Froggatt \& Lowe 1990) forms a discontinuous brownish-grey medium ash layer up to $2 \mathrm{~cm}$ in thickness, and was erupted in 1886 AD from Tarawera volcano in the Okataina Volcanic Centre (OVC).

Kaharoa Tephra is a $5 \mathrm{~cm}$-thick layer comprising greyish-brown fine pumiceous ash over brownish-grey coarse pumiceous ash with a few fine lapilli, and is dominated by biotite, a diagnostic mineral for this tephra (Table 1; Froggatt \& Lowe 1990). Erupted from Tarawera volcano in the OVC, it has an error-weighted mean age (EMA; using the formula of Gupta \& Polach 1985) of $770 \pm 20$ yr B.P. $(n=15$, Froggatt \& Lowe 1990). However, Lowe \& Hogg (1992) suggested that Kaharoa Tephra may have erupted around, or soon after, c. 700 yr B.P., based on new dates with an EMA of $665 \pm 17$ yr B.P. $(n=4)$. Consequently, we have adopted an age of 700 yr B.P. for Kaharoa Tephra here.

Taupo Tephra is a cream-coloured, $4 \mathrm{~cm}$-thick layer of pumiceous coarse ash and lapilli, the latter readily crushed between fingernails. It is derived from Taupo Volcanic Centre (TVC) and is dominated by hypersthene, typical of Holocene tephras from this source (Table 1; Froggatt \& Lowe 1990). Taupo Tephra corresponds to Unit $Y$ in the nomenclature of Wilson (1993). It has an EMA of $1850 \pm 10 \mathrm{yr}$ B.P. $(n=41$, Froggatt \& Lowe 1990), which we have adopted here.

Whakaipo Tephra forms a $1 \mathrm{~cm}$-thick layer of brownish-stained fine ash. It is dominated by hypersthene (Table 1). Correlation was aided by major element analysis of glass from the equivalent tephra in another core from Papamoa Bog (BP3, Fig. 1B): glass from this layer (sample WG21, Table 2) closely matches analyses of Whakaipo Tephra from other environments, including lakes in the Waikato region (Table 2). The composition of glass from Whakaipo Tephra differs from that of other Holocene eruptives from TVC in having lower $\mathrm{CaO}$ and $\mathrm{FeO}$ concentrations (Lowe 1988b; Stokes et al. 1992). The two radiocarbon

\footnotetext{
*All ages reported and discussed in the text are conventional radiocarbon ages based on the Libby (old) half-life of 5568 years. Wk- numbers are University of Waikato Radiocarbon Dating Laboratory numbers (Hogg et al. 1987).
} 


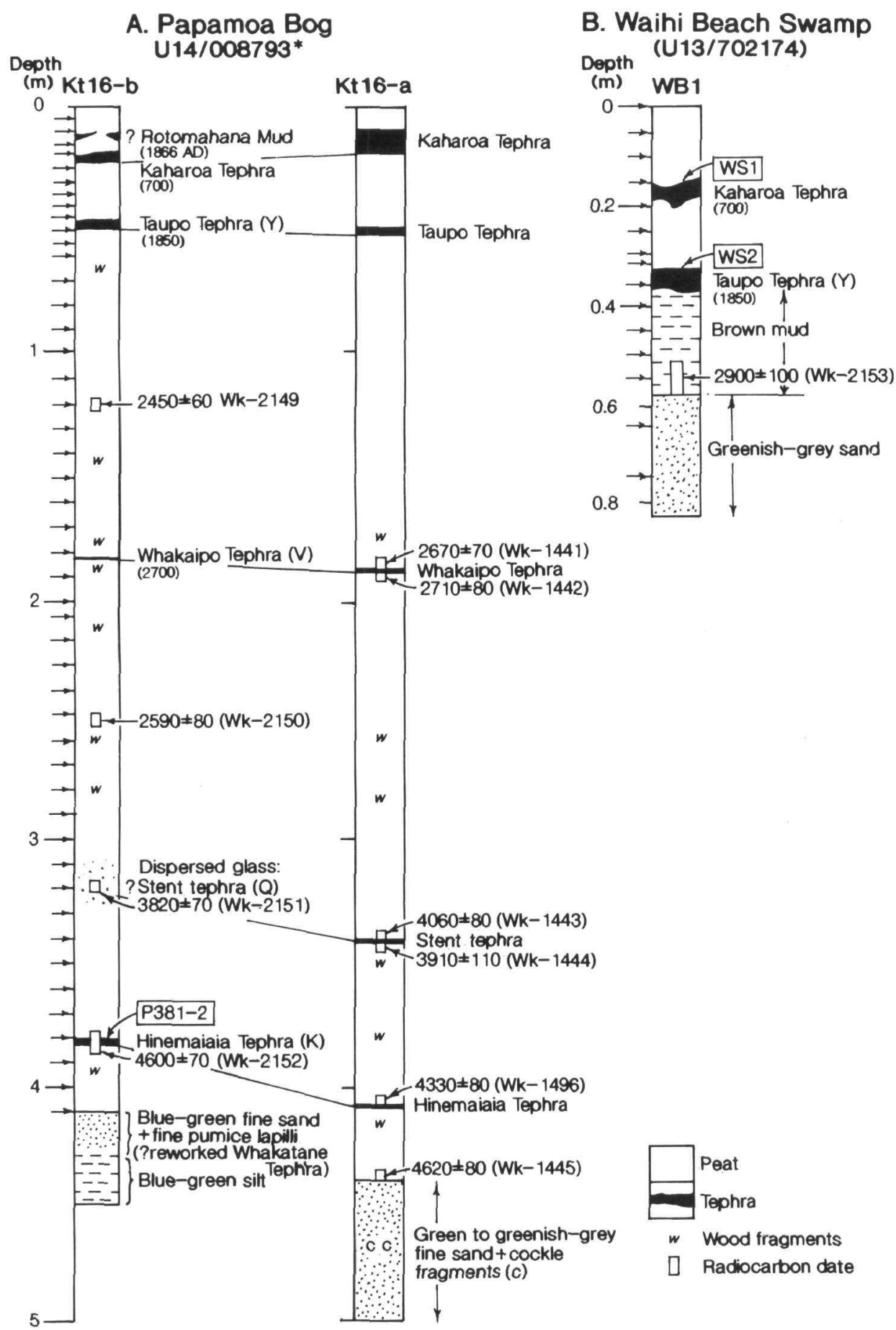

Fig. 2 - Stratigraphy and chronology of cores from (A) Papamoa and (B) Waihi Beach. Tephra names follow the nomenclature of Froggatt \& Lowe (1990); the letters in parentheses are likely correlatives of Taupo eruptives using Wilson's (1993) terminology. Ages are discussed in the text. Arrows mark pollen sampling positions (see text). ${ }^{*}$ Grid references are based on the metric 1:50 000 topographical map series NZMS 260. 
Table 1 - Ferromagnesian mineralogy of tephra layers identified in peats at Papamoa, based on point counts using optical microscopy (Wigley 1990).

\begin{tabular}{lccccc}
\hline Tephra & $\mathbf{n}$ & Hyp & Aug & Hble & Bio \\
\hline Trm & 1 & 36 & 7 & 10 & 47 \\
$\mathrm{Ka}$ & 2 & $24-29$ & $1-2$ & $14-16$ & $53-61$ \\
Tp & 6 & $73-84$ & $5-21$ & $2-11$ & 0 \\
$\mathrm{Mp}^{*}$ & 3 & $85-89$ & $2-9$ & $1-7$ & $0-6$ \\
Wo $^{*}$ & 4 & $88-96$ & $3-10$ & $1-2$ & $0-1$ \\
$\mathrm{St}^{*}$ & n.d. & & & & 0 \\
$\mathrm{Hm}$ & 1 & 81 & 15 & 4 & 0 \\
\hline
\end{tabular}

n.d. $=$ not determined; $\mathrm{n}=$ no. of samples

Hyp $=$ hypersthene; Aug $=$ augite $;$ Hble $=$ calcic hornblende $;$ Bio $=$ biotite

"Mapara Tephra (c. $2160 \pm 25$ yr B.P., Unit X of Wilson 1993) was not observed in the core analysed for pollen, but was identified at other Papamoa sites (Wigley 1990; Lowe et al. 1992).

\# Dominant mineral is hypersthene (Alloway et al. 1994).

Trm = Tarawera Tephra (Rotomahana Mud); Ka = Kaharoa Tephra; $\mathrm{Tp}=$ Taupo Tephra (Unit Y); Wo = Whakaipo Tephra (Unit V); St = Stent tephra (Unit Q); Hm = Hinemaiaia Tephra $($ Unit K).

dates obtained from core Kt16-a (Wk-1441, Wk-1442) have an EMA of $2690 \pm 55$ yr B.P., identical to the EMA of $2685 \pm 20(n=13)$ reported by Froggatt $\&$ Lowe $(1990)$ for this tephra, so we adopted the age of 2700 yr B.P. Whakaipo Tephra corresponds to Unit V, aged 2700 yr B.P. (Wilson 1993).

Stent tephra (informally named by Alloway et al. 1994) is found as a $2 \mathrm{~cm}$-thick layer of whitish-grey medium ash in core Kt16-a and as sparse, disseminated glass in Kt 16-b (Fig. 2A). Five radiocarbon dates were obtained on Stent tephra at Papamoa Bog (three from cores Kt16a-b; two from core BP3: Alloway et al. 1994), and the EMA of these is $3990 \pm 40 \mathrm{yr}$ B.P. An age of $4000 \mathrm{yr}$ B.P. is therefore adopted here. Alloway et al. (1994) tentatively correlated the Stent tephra, derived from TVC, with Unit Q of Wilson (1993), which has an estimated age of 4050 yr B.P.

Hinemaiaia Tephra is found near the base of the peat as a $2.5 \mathrm{~cm}$-thick, whitish-grey medium ash layer (Fig. 3A). Derived from TVC, it has a mineralogy dominated by hypersthene (Table 1). Analysis of glass from Kt16-b (sample P381-2) supports a Taupo origin and matches analyses from Hinemaiaia Tephra identified in Waikato lakes (Table 2). The two radiocarbon dates obtained from core $\mathrm{Kt} 16 \mathrm{a}-\mathrm{b}(\mathrm{Wk}-1496, \mathrm{Wk}-2152)$ differ from each other by several hundred years (Fig. 2A). They have an EMA of $4485 \pm 55 \mathrm{yr}$ B.P. (if the underlying sample $\mathrm{Wk}-1445$ is included, the EMA is $4525 \pm 45 \mathrm{yr}$ B.P.), close to the EMA of $4510 \pm 20$ yr B.P. $(n=12)$ reported by Froggatt \& Lowe $(1990)$ for Hinemaiaia Tephra. It is likely that the tephra we refer to as Hinemaiaia at Papamoa Bog is a correlative of Wilson's (1993) Unit K, the most widely dispersed of the Taupo-derived tephras erupted in the period from c. 4000 to $5000 \mathrm{yr}$ B.P. Unit K has an estimated age of $4600 \mathrm{yr}$ B.P. (Wilson 1993). We thus adopted this age (identical to Wk-2152 from Kt 16-b, anyway) for Hinemaiaia Tephra in our study.

Microscopic analysis of the ferromagnesian mineralogy of the fine sand and pumice lapilli underlying the peat (at $4.2-4.3 \mathrm{~m}$ depth) in core $\mathrm{Kt} 16$-b showed an assemblage dominated by cummingtonite with biotite, hypersthene, augite, calcic hornblende, opaque minerals, and very rare aegirine. Such an assemblage, apart from the aegirine, is characteristic of OVC eruptives, with the abundant cummingtonite indicating a source specifically from Haroharo volcano (Froggatt \& Lowe 1990). It is very likely therefore that the fine pumice lapilli represent Whakatane Tephra, a cummingtonite-rich tephra with an EMA of $4830 \pm 20 \mathrm{yr}$ B.P. 

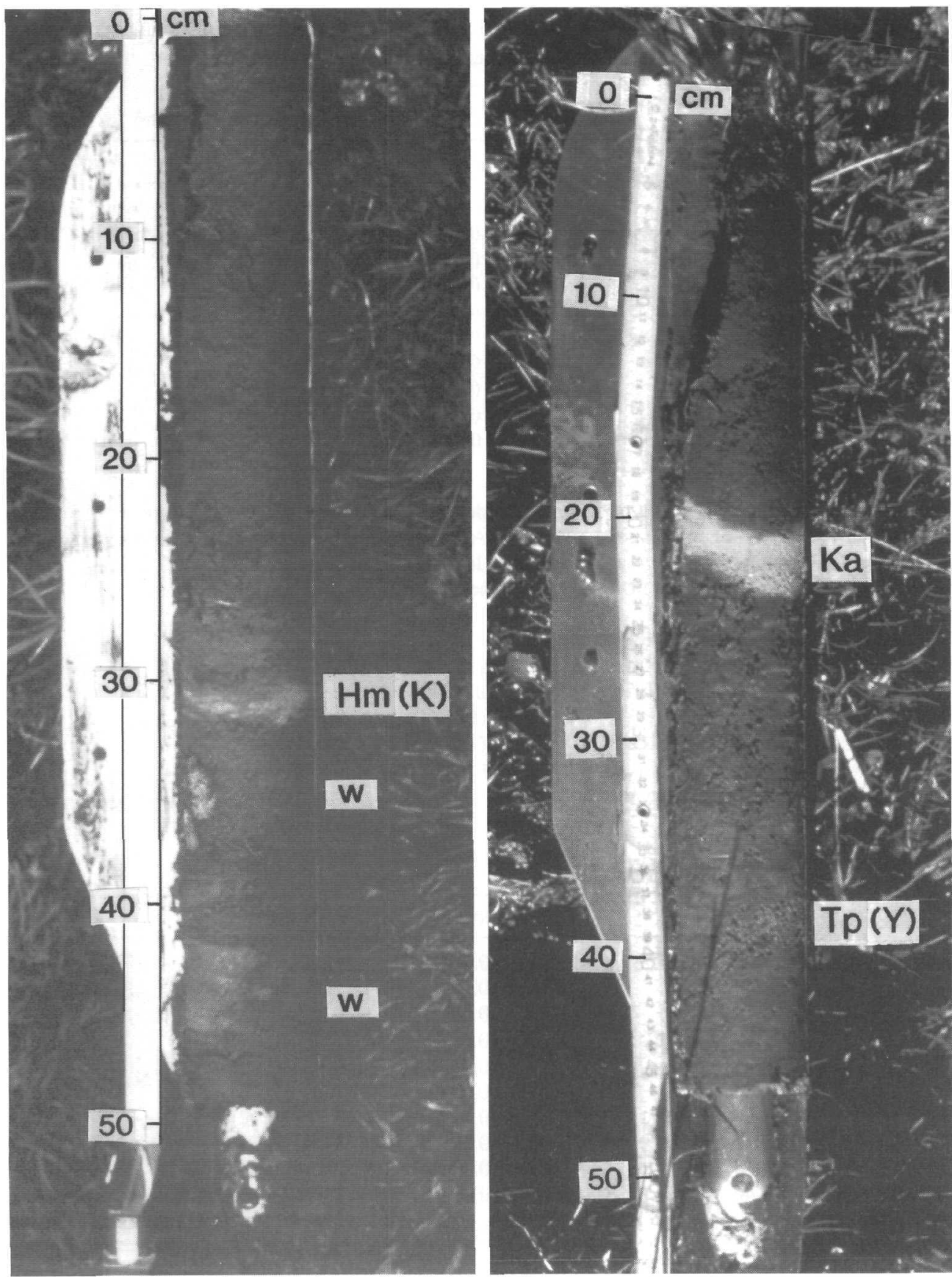

Fig. 3(A) - Part of core Kt16-b showing Hinemaiaia Fig. 3(B) - Part of core WB1 showing Kaharoa Tephra (Hm; Unit K of Wilson 1993), and wood Tephra (Ka) and Taupo Tephra (Tp; Unit Y of fragments (w). Wilson 1993). Photos: D.J. Lowe. 
Table 2 - Glass compositions* of Kaharoa, Taupo, Whakaipo, and Hinemaiaia tephras at Papamoa and Waihi Beach, and comparative analyses from elsewhere.

\begin{tabular}{|c|c|c|c|c|}
\hline & \multicolumn{2}{|c|}{ Kaharoa } & \multicolumn{2}{|c|}{ Taupo (Unit Y) } \\
\hline & $\mathrm{WS} 1^{\mathrm{d}}$ & Mt Tarawera ${ }^{\mathrm{c}}$ & $\mathrm{WS}^{\mathrm{d}}$ & Waikato $^{f}$ \\
\hline $\mathrm{SiO}_{2}$ & $78.46 \quad(0.40)$ & $78.34 \quad(0.21)$ & $76.58 \quad(1.10)$ & $76.43 \quad(0.64)$ \\
\hline $\mathrm{Al}_{2} \stackrel{2}{\mathrm{O}}_{3}$ & $12.31 \quad(0.11)$ & $12.50 \quad(0.12)$ & $12.90(0.46)$ & $13.05 \quad(0.23)$ \\
\hline $\mathrm{TiO}_{2}{ }^{3}$ & $0.14 \quad(0.06)$ & $0.11(0.02)$ & $0.22(0.05)$ & $0.23 \quad(0.05)$ \\
\hline $\mathrm{FeO}^{\frac{2}{b}}$ & $0.88 \quad(0.14)$ & $0.80 \quad(0.08)$ & $1.75 \quad(0.32)$ & $1.81 \quad(0.19)$ \\
\hline $\mathrm{MgO}^{\mathrm{a}}$ & $0.10 \quad(0.05)$ & $0.10 \quad(0.01)$ & $0.22 \quad(0.07)$ & $0.22 \quad(0.05)$ \\
\hline $\mathrm{CaO}$ & $0.72 \quad(0.17)$ & $0.61 \quad(0.05)$ & $1.41 \quad(0.27)$ & $1.31 \quad(0.16)$ \\
\hline $\mathrm{Na}_{2} \mathrm{O}$ & $3.53(0.16)$ & $3.22(0.15)$ & $3.77 \quad(0.35)$ & $3.97 \quad(0.31)$ \\
\hline $\mathrm{K}_{2} \mathrm{O}$ & $3.78 \quad(0.15)$ & $4.21 \quad(0.14)$ & $2.99 \quad(0.39)$ & $2.84 \quad(0.17)$ \\
\hline $\mathrm{Cl}^{2}$ & $0.15(0.03)$ & $0.16 \quad(0.02)$ & $0.16(0.03)$ & $0.14 \quad(0.03)$ \\
\hline Water & $2.18(1.67)$ & $3.05 \quad(0.93)$ & $1.71 \quad(1.70)$ & 3.21 (1.83) \\
\hline $\mathrm{n}$ & 9 & 11 & 10 & 10 \\
\hline
\end{tabular}

"Means and standard deviations (in parentheses) as determined by JEOL-JXA-733 electron microcrobe at Victoria University of Wellington, using $8 \mathrm{nA}$ beam current at $15 \mathrm{kV}$ and defocussed to 10 micrometres (Froggatt 1983); normalised to $100 \%$ loss-free

a Analyses were below detection in some shards; these values omitted from the means

${ }^{b}$ Total $\mathrm{Fe}$ as $\mathrm{FeO}$

${ }^{c}$ Difference between analytical total and 100

${ }^{d}$ Sample from Waihi Beach Swamp (Fig. 2A) (this study; analyst P.C. Froggatt)

e Sample from Mt Tarawera Rift (from Hodder et al. 1991)

${ }^{f}$ Sample from Lake Rotomanuka, Waikato region (from Lowe 1988a)

"Sample from Papamoa Bog (Core BP3, Fig. 1B) (Alloway et al. 1994)

${ }^{\text {h }}$ Sample from Papamoa Bog (core Kt16-b, Fig. 1B) (Alloway et al. 1994)

$n$ Number of analyses (individual shards) in mean

Table 2 Continued

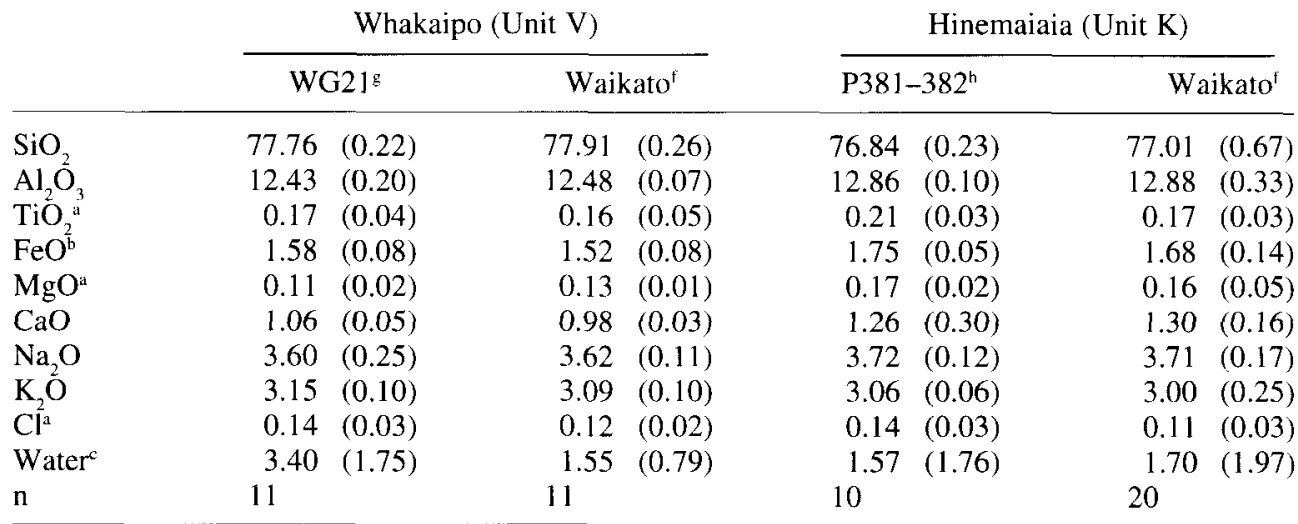

( $n=21$, Froggatt \& Lowe 1990). Aegirine is unique to Tuhua Tephra, which has an EMA of $6130 \pm 30(n=10)$ (Lowe 1988a, b; Froggatt \& Lowe 1990). The mixture of cummingtonite and aegirine thus indicates that the basal sediments comprise mainly reworked Whakatane Tephra plus a trace of Tuhua Tephra, a notion consistent with the estuarine environment in which the sediments were deposited, and with the age on the cockles (reported above), i.e., the basal sands must date from c. 4800 yr B.P. (Airfall Whakatane Tephra was identified in dune systems in the Rangitaiki Plains in eastern bay of Plenty; Pullar \& Selby 1971.) 
Two further radiocarbon dates, in addition to those obtained in association with the tephra layers, were assayed from core Kt16-b: Wk-2149 and Wk-2150 (Fig. 2A). Wk-2149 is consistent with the tephrochronology we have established, but Wk-2150 is not, being apparently younger than Whakaipo Tephra $0.65 \mathrm{~m}$ above it in the core (Fig. 4A). We have therefore omitted it from our pollen diagram chronology.

\section{Waihi Beach Swamp}

Core WB1 (Fig. 2B) comprises basal sands of likely estuarine origin overlain by sticky, brown, organic-rich muds, and blackish peat, intercalated with two macroscopic tephra layers (Fig. 3B). A radiocarbon date of $2900 \pm 100 \mathrm{yr}$ B.P. (Wk-2153) at the base of the brown muds indicates that infilling of the estuarine embayment began around that time.

\section{Tephrochronology}

The upper tephra layer, identified as Kaharoa Tephra, is $4 \mathrm{~cm}$ thick and comprises white, fine pumiceous ash over coarse ash with sparse fine, hard lapilli towards the base. Abundant biotite is evident in hand specimen, and the major element chemistry of glass at Waihi Beach (sample WS1, Fig. 2B) closely matches that of Kaharoa Tephra at source (Table 2). As at Papamoa, we adopt an age of $700 \mathrm{yr}$ B.P. for the tephra here.

The lower tephra layer is identified as Taupo Tephra, a brownish-stained coarse ash and fine lapilli deposit $4 \mathrm{~cm}$ thick. Correlation is based on its field properties and stratigraphic position between $\mathrm{Wk}-2153$ and Kaharoa Tephra, and corroborated by the similarity of the major element chemistry of its glass (sample WS2, Fig. 2B) to Taupo Tephra from other environments, including Wakato lakes (Table 2). We adopt an age of $1850 \mathrm{yr}$ B.P. for Taupo Tephra (Unit Y of Wilson 1993) at Waihi Beach, as discussed above for Papamoa.

Both tephras were recorded by Pullar et al. (1977) in a core taken from another part of Waihi Beach Swamp (core P, Fig. 1A).

\section{PEAT ACCUMULATION RATES}

\section{Papamoa}

Rates of peat accumulation for core Kt16-b are plotted in Fig. 4A. From 4600 to $2700 \mathrm{yr}$ B.P., peat accumulated between 0.94 and $1.06 \mathrm{~mm} / \mathrm{yr}$, increasing markedly to $2.64 \mathrm{~mm} / \mathrm{yr}$ from 2700 to $2450 \mathrm{yr}$ B.P., and returning to $1.15 \mathrm{~mm} / \mathrm{yr}$ from 2450 to $1850 \mathrm{yr}$ B.P. The mean rate for this period is $1.37 \mathrm{~mm} / \mathrm{yr}$. The rate of accumulation since Taupo Tephra is likely to be severely underestimated because there has been considerable shrinkage of the bog's surface layers in historical times.

The rates are comparable with those reported for the large ombrogenous bogs in the Hauraki Lowlands (mean $0.86 \pm 0.67 \mathrm{~mm} / \mathrm{yr}$ for central and southern, and $1.68 \pm 0.87 \mathrm{~mm} / \mathrm{yr}$ for northern, parts of Kopouatai Bog; Newnham et al. 1995), but around ten times faster than those of some other Holocene bogs in central North Island (e.g., $0.19 \mathrm{~mm} / \mathrm{yr}$ for both Holden's Bay, Rotorua, and Kaipo Lagoon, Urewera National Park: McGlone 1983; Lowe \& Hogg 1986), and at Waihi Beach Swamp (see below). The rates of acumulation may vary for many reasons including climatic variation, influxes of nutrients, changes in sea level or ground level (tectonism), or geomorphic events causing changes in drainage patterns. At Papamoa, the initiation and rapid growth of the bog from just before c. $4600 \mathrm{yr}$ B.P. was probably due in part to a net rise in water table, either by local tectonic subsidence, as suggested by Wigley (1990) for the Te Puke area (and for the Rangitaiki Plains by Nairn \& Beanland 1989), or by a small rise $(\approx 1 \mathrm{~m})$ in sea level c. $4600 \mathrm{yr}$ B.P., as suggested by Hull (1985) and Gibb (1986). At Kopouatai Bog, Hauraki Lowlands, changes in trophic status and peat accumulation rates were influenced by mid-Holocene sea level changes (Newnham et al. 1995). Sea levels have apparently oscillated by only a few tens of centimetres since then (e.g., see Woodroffe et al. 1983; Gibb 1986; Naish 1990). The initial bog development at Papamoa may also have been aided by a substrate of nutrient-rich estuarine sediments, and 

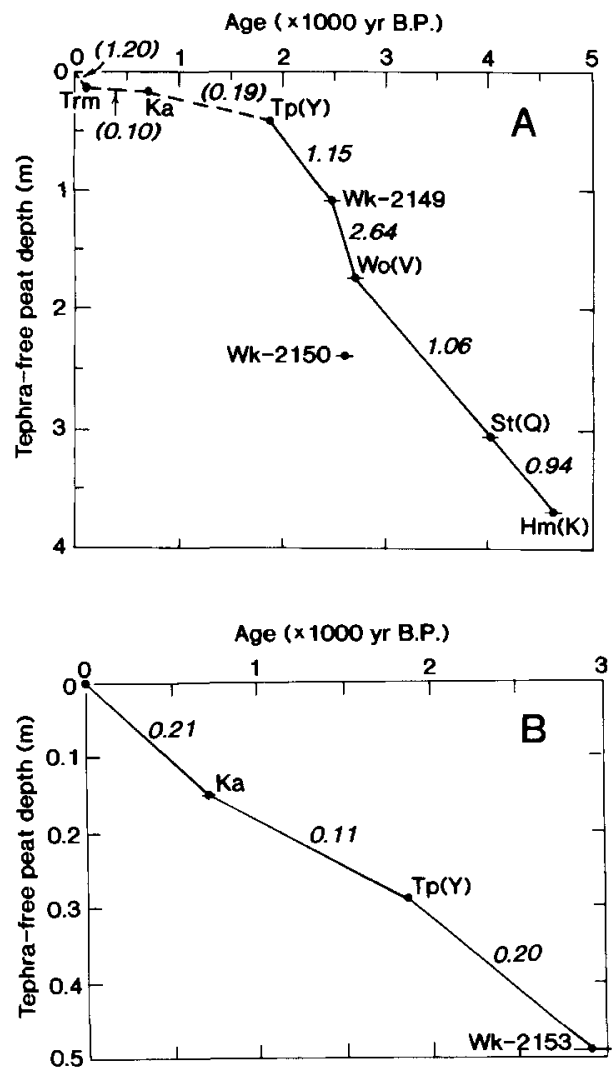

Fig. 4 - Peat depth-age curves for cores (A) Kt 16-b at Papmoa, and (B) WB1 at Waihi Beach. Tephra abbreviations are as in Table 1. Sedimentation rates between dated points are shown in italics. At Papamoa, the rate of accumulation since Taupo Tephra (Tp) was deposited is probably grossly underestimated (see text). enhanced by occasional influxes of nutrientbearing flood waters. Variations in local drainage conditions are also likely to have influenced development.

\section{Waihi Beach}

The rates of peat accumulation since $2900 \mathrm{yr}$ B.P. are plotted in Fig. 4B. From 2900 to 1850 yr B.P., the rate is $0.20 \mathrm{~mm} / \mathrm{yr}$; from 1850 to $700 \mathrm{yr}$ B.P. it slows to $0.11 \mathrm{~mm} / \mathrm{yr}$; and from $700 \mathrm{yr}$ B.P. to the surface (assumed to represent present day), it is $0.21 \mathrm{~mm} / \mathrm{yr}$. The extent to which partial drainage has affected peat thickness is unknown, but the depths are comparable with those recorded by Pullar et al. (1977), suggesting that there has been rather little shrinkage over the past c. 20 years. The mean rate of accumulation for the entire period from $2900 \mathrm{yr}$ B.P. to the present day is $0.20 \mathrm{~mm} /$ year, considerably slower than that at Papamoa prior to deposition of Taupo Tephra (Fig. 4A).

\section{PALYNOLOGY \\ Methods and results}

Pollen samples were analysed from the base of the Papamoa Bog core at $410 \mathrm{~cm}$, at $20 \mathrm{~cm}$ intervals from $400 \mathrm{~cm}$ to $60 \mathrm{~cm}$, and at $5 \mathrm{~cm}$ intervals from $50 \mathrm{~cm}$ to $10 \mathrm{~cm}$ (Fig. 2A). The closer sampling interval reflects our particular interest in the last 2000 years. Samples at 400 and $380 \mathrm{~cm}$ yielded very little or no pollen and are not included in the pollen diagrams. All other samples yielded sufficient numbers to achieve a minimum sum of 250 dryland pollen.

Pollen samples were taken at $10 \mathrm{~cm}$ intervals from the base of the Waihi Beach core $(75 \mathrm{~cm})$ to $55 \mathrm{~cm}$, and thereafter at $5 \mathrm{~cm}$ intervals except where tephra layers intervened (Fig. 2B). Pollen recovery was generally good, except in the uppermost two samples, where levels of indigenous dryland pollen taxa were comparatively low. Microscope slides were prepared following standard procedures (Faegri \& Iversen 1989) including hydrofluoric acid treatment. Tablets of exotic Lycopodium spores were added to each sample to permit the determination of pollen concentrations and accumulation rates. Charcoal concentrations were estimated using the point count method described by Clark (1982) for the Papamoa Bog samples, and using the nitric acid digestion method described by Winkler (1985) for the Waihi Beach samples. Besides mire taxa, ferns and allies taxa, and exotic taxa, Leptospermum was omitted from the pollen sum at both sites, because high numbers of this taxon suggested the local presence of Leptospemum scoparium or Kunzea ericoides. Several grains of walnut (Juglans) pollen were recorded in the Papamoa samples between 430 and $100 \mathrm{~cm}$ depth. As this tree has only recently been introduced into New Zealand, this record is assumed to have resulted from contamination of the samples after the core was extracted.

The pollen profiles at both sites are divided into three time intervals, as follows: 

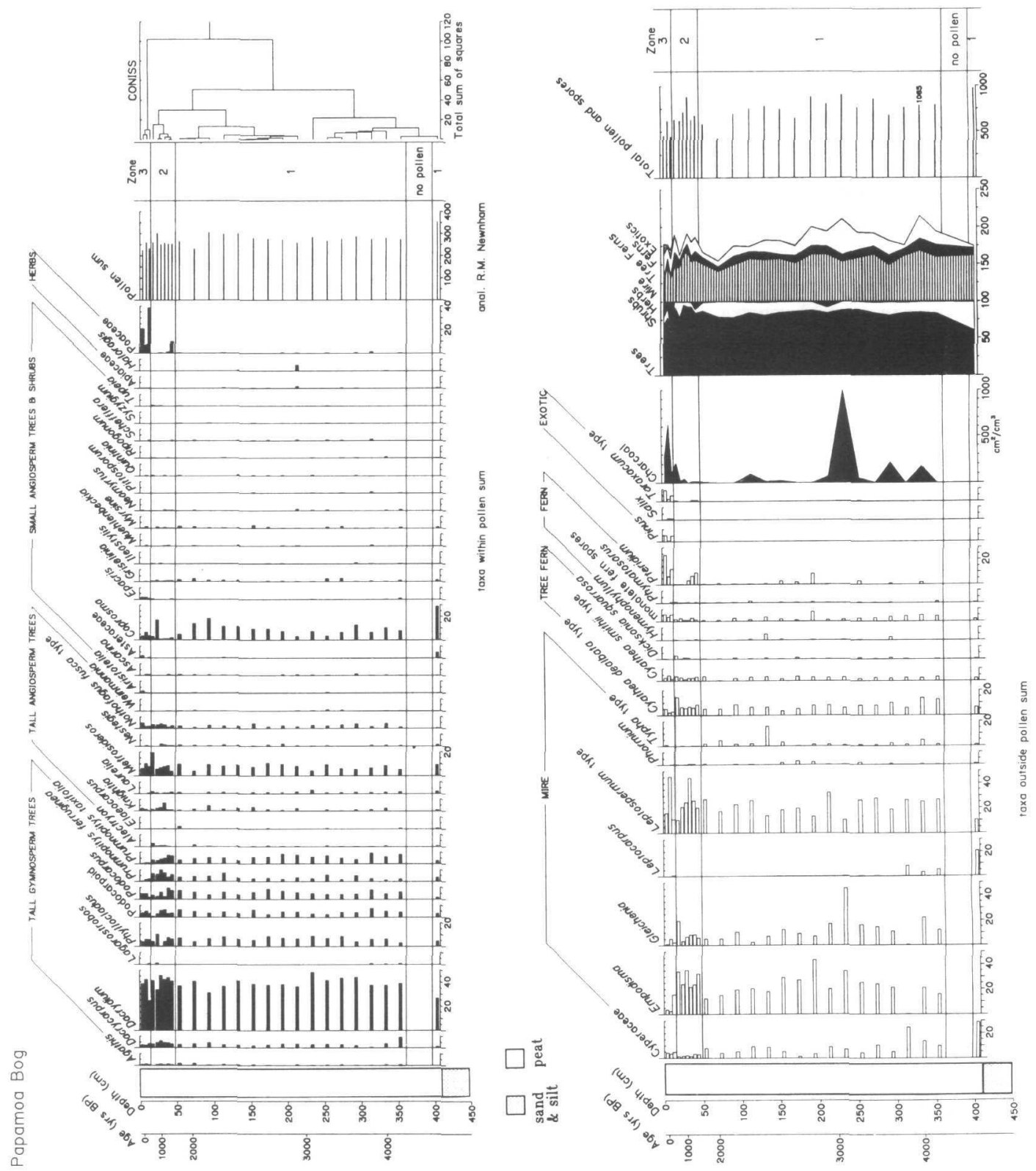

Fig. 5 - Pollen percentage diagram for core Kt16-b, Papamoa Bog.

Zone 3: Top of core to Kaharoa Tephra (c. 700 yr B.P.)

Zone 2: Kaharoa Tephra (c. 700 yr B.P.) to Taupo Tephra (c. 1850 yr B.P.)

Zone 1: Taupo Tephra (c. 1850 yr B.P.) to bottom of core (c. 4600 yr B.P. at Papamoa; c. 2900 yr B.P. at Waihi Beach).

Pollen diagrams and cluster analyses (CONISS) were generated using the software package TILIA (Grimm 1987). 


\section{Papamoa Bog (Fig. 5)}

Time Zone 1: c. 4600 - 1850 yr B.P.

The lowermost spectra are characterised by high levels of Leptocarpus, Cyperaceae and Coprosma pollen. Leptocarpus and Cyperaceae pollen levels then decline, and Leptocarpus disappears from the record after c. 4600 yr B.P. Meanwhile, Empodisma pollen and Gleichenia spores increase to high levels. These changes are associated with a sediment transition from black peat to sludgy brown peat. Cyperaceae pollen remains important, although at lower levels than in the lowermost spectra, and possibly other sedge species are now present. Other important mire taxa in this zone are Leptospermum, Typha, especially in the upper part of the zone, and Phormium, especially in the lower to middle part of the zone. Pteridium spores are common in several spectra, as are charcoal fragments, particularly at $240 \mathrm{~cm}$.

Dryland pollen spectra are dominated by Dacrydium, with other prominent Podocarpaceae taxa including Dacrycarpus, Phyllocladus, Podocarpus, and Prumnopitys. Agathis australis pollen is consistently present in this zone but never exceeds $2 \%$. Metrosideros species are the dominant angiosperm pollen taxa, and numerous other angiosperm trees and shrubs are present, including Nothofagus fusca type. Cyathea dealbata type spores are also prominent.

Time Zone 2: c. $1850-700$ yr B.P.

The lower part of this zone is characterised by strong increases in Pteridium spores and Poaceae pollen at, and shortly after, the time of the Taupo eruption of $1850 \mathrm{yr}$ BP. This evidence suggests that vegetation disturbances caused by the eruption extended to a considerable distance from its source, although the local mire vegetation and regional conifer-angiosperm forests remained largely unaffected. Pteridium and Poaceae levels return to zero $15 \mathrm{~cm}$ above the tephra, suggesting that the disturbance interval was short. Fire, apparently, was not involved.

\section{Time Zone 3: c. 700 yr B.P. to near-present}

Charcoal concentrations rise immediately below Kaharoa Tephra and remain comparatively high to the top of the sequence. Exotic pollen, particularly Pinus and Salix are first recorded immediately above the Kaharoa Tephra. Taraxacum type pollen is also common in this zone, and may also be from adventive taxa. Poaceae pollen and Pteridium spores are also at their highest levels. Tree pollen percentages are lower overall than in the previous zone, with a notable decline in Prumnopitys spp.

\section{Discussion}

The lowermost pollen spectra at Papamoa Bog, from sediments overlying sand, indicate a coastal or estuarine Leptocarpus similis/Cyperaceae marsh. After around $4600 \mathrm{yr}$ B.P., the pollen record indicates a decline of these coastal/estuarine communities and a transition to an early oligotrophic or low moor bog, with Empodisma minus and Gleichenia dicarpa prominent. Fire was associated with the bog environment. Pollen of raupo (Typha orientalis) and flax (Phormium tenax) probably originated from lagg vegetation at the margins of the bog. An increase in Phormium pollen (an under-represented pollen taxon) at $200 \mathrm{~cm}$, followed by an increase in Typha pollen at $160 \mathrm{~cm}$, and the simultaneous decline in Empodisma pollen and Gleichenia spore levels, suggests that more parts of the bog were subject to eutrophic conditions at this time than at any other time during its history. This period, spanning the 1000 or so years before the deposition of the Taupo Tephra at $1850 \mathrm{yr}$ B.P., encompasses the period of most rapid peat accumulation at Papamoa Bog (Fig. 4A) The bog has persisted to the present day, judging by the Empodisma pollen curve, although the bog vegetation has been greatly reduced during the European era.

The regional dryland vegetation consisted primarily of diverse conifer-angiosperm forest, which persists to the European era. At least some Coprosma pollen may have originated from mire communities, particularly in the lowermost spectrum, where Coprosma reaches almost 

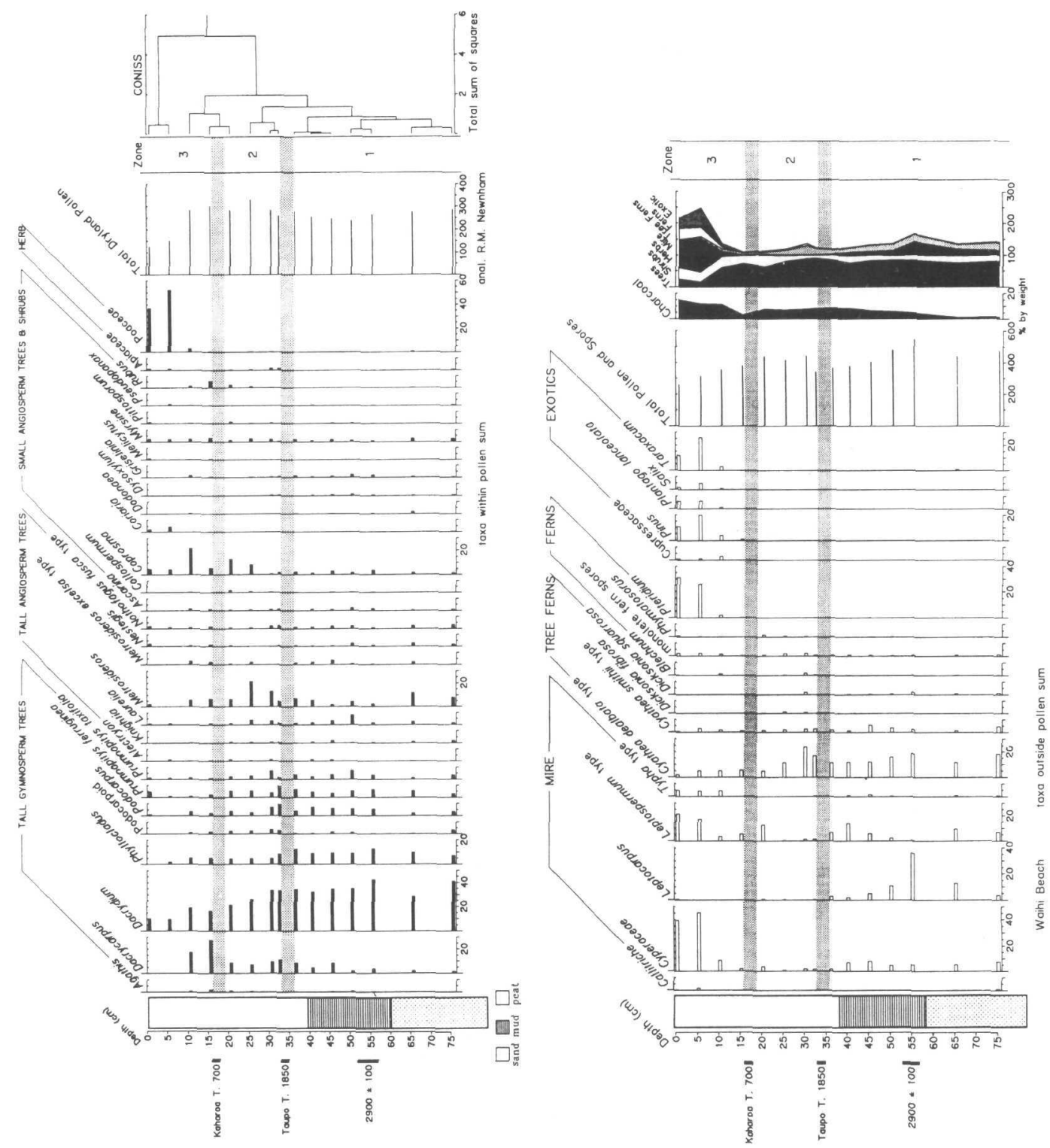

Fig. 6 - Pollen percentage diagram for core WB1, Waihi Beach Swamp.

$30 \%$ of 'dryland pollen'. Similarly, kahikatea (Dacrycarpus dacrydioides) and Laurelia novae-zelandiae (pukatea) trees probably grew on swampy ground at the margins of the marsh or bog. The comparatively low (for this taxon) levels of Nothofagus pollen suggest that beech forests were present, but at distant localities, probably in the Kaimai or Coromandel Ranges (Newnham et al. 1995). Forests declined during the European era.

Campbell et al. (1973) reported plant macrofossils and tephra layers from cored sediments spanning the last c. 3000 years taken at a site c. $1 \mathrm{~km}$ to the northeast of our core site and within the same bog system (Fig. 1B). Peats below the Kaharoa Tephra contained macrofossils derived from a Baumea-dominated low moor bog with Gleichenia, Empodisma, Cortaderia and dwarf trees or short-lived seedlings of Dacrycarpus and Laurelia. Above this tephra 
layer, the peat had been greatly altered by farming. These macrofossil data are broadly consistent with the Papamoa pollen data, except that the early coastal communities were not detected in the macrofossil core, presumably because it did not extend to sufficient depth.

\section{Waihi Beach Swamp (Fig. 6)}

Time Zone 1: c. $2900-1850$ yr B.P.

This pollen zone encompasses two sediment types: the greenish grey sands at the base of the core and the overlying sticky brown muds. Leptocarpus pollen is abundant although declining towards the top of the zone, while Cyperaceae and Leptospermum pollen is common. Numerous other wetland taxa were recorded including Typha, Potamogeton, Myriophyllum, Callitriche, Avicennia and Apiaceae.

Dryland pollen assemblages are dominated by podocarp taxa, especially Dacrydium, and to a lesser extent, Phyllocladus and Prumnopitys. Dacrycarpus pollen levels increase towards the top of the zone. Prominent tall angiosperm tree taxa are Laurelia, Metrosideros, Alectryon, Knightia and Nestegis, while smaller tree and shrub taxa include Ascarina, Coprosma, Dodonaea, Dysoxylum, Griselinia, Myrsine, Pittosporum, and Pseudopanax. Cyathea dealbata type tree fern spores are common.

Time Zone 2: c. 1850 - 700 yr B.P.

Peat replaced the sticky brown mud of the uppermost part of the previous zone. Palynologically, the major change is the near-disappearance of Leptocarpus pollen from the record, and the reduced representation of many of the other coastal marsh taxa of the previous zone.

Few changes are evident in the dryland taxa, but overall there is an increase in smaller tree and shrub pollen, particularly Coprosma. Levels of podocarp pollen fall, except for Dacrycarpus which increases to a peak of $25 \%$ at the top of the zone.

Time Zone 3: c. 700 yr B.P. to near-present

Charcoal concentrations rise steadily and the pollen of exotic taxa, notably Pinus, Cupressaceae, Salix, Plantago lanceolata, and Taraxacum are found throughout. Levels of Poaceae pollen and Pteridium spores also increase dramatically, as do the pollens of some other herbaceaous and shrubby taxa, e.g., Apiaceae and Coriaria. At the same time, total tree pollen percentages fall from $80 \%$ at the base of the zone to $25 \%$ at the top, with most individual tree taxa showing a marked decline, particularly Dacrycarpus. In the wetland taxa, Cyperaceae, Leptospermum, and Typha pollen levels increase markedly.

\section{Discussion}

The abundance of Leptocarpus and Cyperaceae pollen, and that of associated wetland taxa, indicate that the site was initially occupied by coastal salt marsh communities, probably regularly flooded at high tide. In time, Leptocarpus gradually declined, as the nature of the sediment accumulating at the site changed from greenish grey sands to organic brown muds. These changes are likely to be related to gradual coastal progradation, or a falling sea level, or both.

After c. 2000 yr B.P., Leptocarpus pollen virtually disappears from the record and peat sedimentation begins at the site. The site was no longer influenced by tidal processes and had become more distant from coastal marsh communities, but closer to kahikatea (Dacrycarpus dacrydioides) swamp forest communities.

At some time following the deposition of Kaharoa Tephra (c. 700 B.P.), the local wetland flora changed again, as swamp forest communities declined near the core site to be replaced by eutrophic sedge-Typha-Leptospermum wetland communities. This last change probably began during the European era, the last 150 years, as it is associated with the rise of adventive pollen.

The dryland pollen spectra indicate that a northern coastal conifer-angiosperm forest 


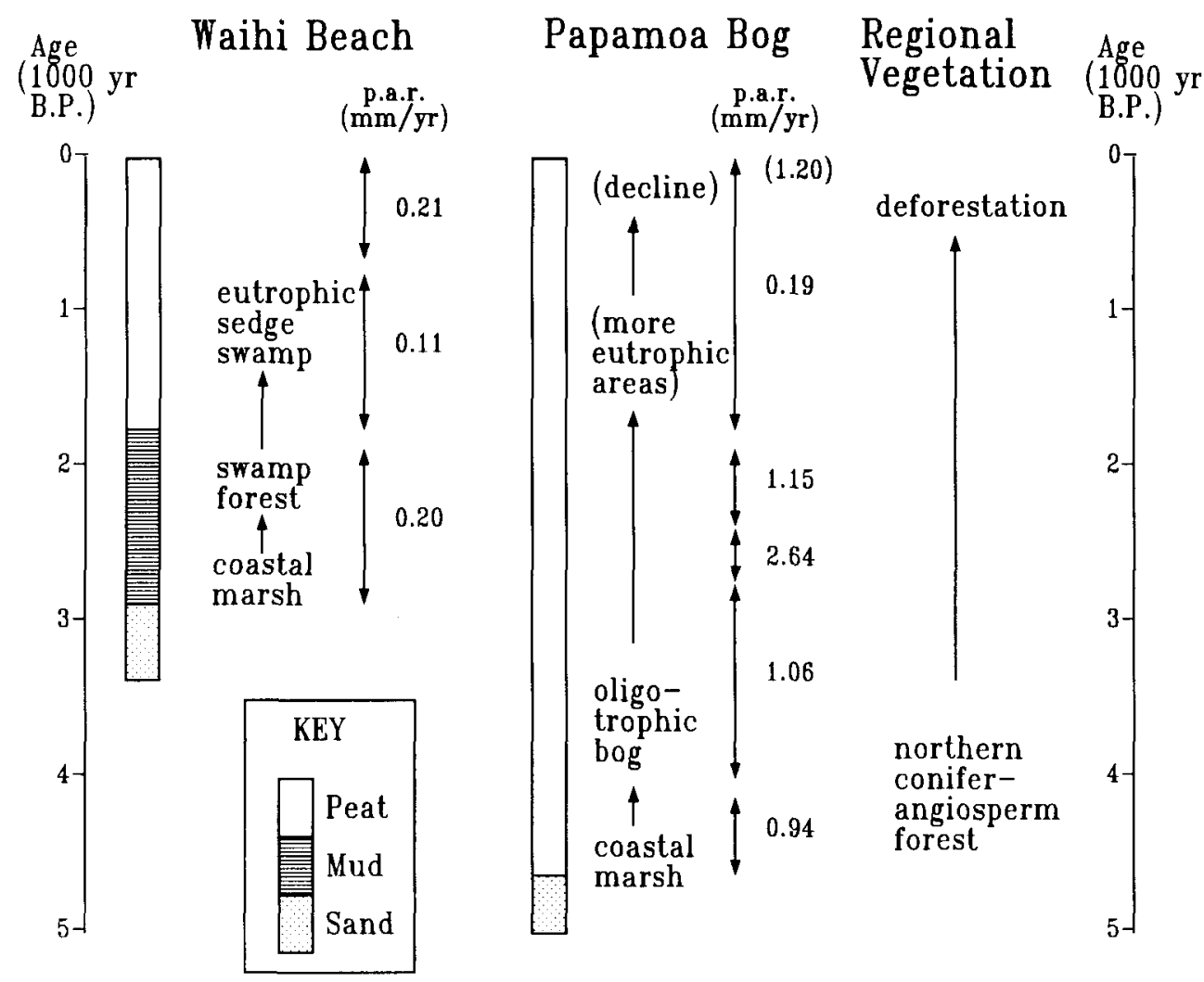

Fig. 7 - Summary of local and regional vegetation history and peat accumulation rates (p.a.r.) from the palynology of cores from Papamoa Bog and Waihi Beach Swamp.

persisted near the site, with few changes apparent until Time Zone 3. Consistently low levels of Nothofagus fusca type pollen levels indicate probable long distance transport from upland sources. In contrast, low levels of Agathis australis pollen are more likely to represent small populations nearer the site, as A. australis pollen does not appear to be as well dispersed as that of Nothofagus (Newnham, 1990). There was significant loss of forest during Time Zone 1 .

\section{SYNTHESIS: LOCAL AND REGIONAL VEGETATION CHANGES}

The local vegetation history at Waihi Beach and Papamoa Bog, and regional vegetation changes in the western Bay of Plenty during the past c. 5,000 years, are summarised in Figure 7. At both sites, organic sediments are underlain by marine or estuarine sands, and the initial local vegetation changes appear to be controlled by either coastal progradation or falling sea level (or both). The basal pollen spectra at both sites indicate local salt marsh or estuarine conditions. At Papamoa, an oligotrophic bog developed at the site soon after c. 4600 years ago and persisted to the present, with considerable reduction during the past 700 years (see below), and an earlier period, between 2800 and $1850 \mathrm{yr}$ B.P., when eutrophic conditions were more prevalent. Except for the uppermost, disturbed peats, peat accumulated rapidly, particularly during the interval 2700 to $2400 \mathrm{yr}$ B.P. At Waihi Beach, the coastal marsh was superseded by kahikatea swamp forest around $2500 \mathrm{yr}$ B.P., which probably persisted until the European era; then a eutrophic mire developed with various sedges and raupo prominent. Peat accumulation here was much slower, especially during the period 1850 to $700 \mathrm{yr}$ B.P. The concurrent development of oligotrophic conditions at Papamoa and mesotrophic or 
eutrophic conditions at Waihi Beach probably relate to differences in local geomorphology, rather than to climatic factors. Although peat accumulation rates may also be influenced by factors other than climate, the slower rates evident at both sites during the period 1850 to 700 yr B.P. point to a drier and/or warmer overall climate during this period.

Both pollen records indicate mixed northern conifer-angiosperm forest as the main regional vegetation type during the past c. 4600 years. Lowland forests probably included a scattering of kauri trees, while beech (Nothofagus fusca group) was most likely present in adjacent uplands, as it still is. Kauri (Agathis australis) populations do not appear to have been expanding during the late Holocene at these sites, which are close to its southern limit today (Allan 1961)

\section{Vegetation disturbance following Taupo Tephra}

Both pollen profiles indicate a generally stable forest environment, occasionally interrupted by fires, such as those responsible for the charcoal peak at $240 \mathrm{~cm}$ depth or the bracken (Pteridium) spore rise at $200 \mathrm{~cm}$. However, more significant disturbance at Papamoa is suggested by the sharp rise in bracken spores and grass pollen in spectra immediately overlying the Taupo Tephra. Similar evidence has been noted at several other pollen sites containing Taupo Tephra but remote from the eruptive centre. At Kohika Swamp, c. $45 \mathrm{~km}$ to the southeast of Papamoa Bog and also on the Bay of Plenty coastal plain (Fig. 1), the Taupo Tephra fall was followed by at least 150 years during which fires were frequent, bracken and grass abundant, and alluvium was washed into the swamp (McGlone 1981). Newnham et al. (1989) reported similar evidence from lake sites in the Waikato lowlands, although there, the disturbance was less severe and probably shorter-lived. At Papamoa, charcoal levels do not rise as at these other sites, suggesting that the post-Taupo Tephra disturbance here was not directly related to fire. Evidence for comparable disturbance was not detected in the pollen spectrum immediately overlying Taupo Tephra at Waihi Swamp $50 \mathrm{~km}$ northwest of Papamoa, although the sediment changes from sticky, brown organic-rich mud below the tephra to peat above it.

\section{Deforestation and the human era}

At both sites, amounts of tree pollen fall as amounts of charcoal, bracken, grass and other herbs and shrubs rise in spectra immediately overlying Kaharoa Tephra. These changes are consistent with those detected at other pollen sites containing Kaharoa Tephra where burning of forests is indicated at around the time of this eruption, that is $700-800 \mathrm{yr} \mathrm{B.P} \mathrm{(e.g.,} \mathrm{see}$ McGlone 1989; McGlone et al. 1994; Newnham et al. 1989, 1995). At Waihi Beach Swamp, the rise of charcoal levels in sediments immediately below Kaharoa Tephra is consistent with evidence from Kopouatai Bog, $35 \mathrm{~km}$ to the northwest, where significant human influence on the vegetation appears to have begun just before the deposition of Kaharoa Tephra (Newnham et al. 1995). However, at both Waihi and Papamoa, these samples also contain significant numbers of adventive pollen, notably pine, willow, and macrocarpa, from trees introduced during the past 150 years. It seems that these adventive pollen grains have filtered down as far as the Kaharoa Tephra, which lies within $20 \mathrm{~cm}$ of the surface at both sites, and may act as a barrier to further movement. Possibly this process has been enhanced by agricultural activity at the surface. The downwards dislocation of modern pollen at these sites blurs any distinctions that might have been made within the human era, in particular distinguishing between the Polynesian and European eras.

\section{ACKNOWLEDGEMENTS}

We thank Jim Dahm and Yoshitaka Ngatomo for help with the coring, Peter de Lange for the description of vegetation at Waihi Beach, and Paul Froggatt for the electron microprobe analyses of tephra-derived glasses. Matt McGlone is especially thanked for providing access to facilities for processing the pollen samples at Landcare Research, Lincoln, for continuing encouragement, and for constructively reviewing the paper. 
Professor A. P. Mark is also thanked for reviewing the paper. Funding support from the University of Waikato Research Committee (DJL) for radiocarbon dating is gratefully acknowledged. Frank Bailey drafted Figs. 1, 2 and 4.

\section{REFERENCES}

Allan, H. H. 1961: Flora of New Zealand, Volume 1. Wellington, Government Printer. 1085 p.

Alloway, B. V.; Lowe, D. J.; Chan, R. P. K.; Eden, D. N.; Froggatt, P. C. 1994: Stratigraphy and chronology of the Stent tephra, a c. 4000 year old distal silicic tephra from Taupo Volcanic Centre, New Zealand. New Zealand journal of geology and geophysics 37: 37-47.

Campbell, E. O.; Heine, J. C.; Pullar, W. A. 1973: Identification of plant fragments and pollen from peat deposits in the Rangitaiki Plains and Maketu Basins. New Zealand journal of botany 11: $317-$ 330.

Clark, R. L. 1982: Point count estimation of charcoal in pollen preparations and thin sections. Pollen et spores 24: 523-535.

Davoren, A. 1978: A survey of New Zealand peat resources. Water and Soil technical publication 14. $157 \mathrm{p}$.

Faegri, K; Iversen, J. 1989: Textbook of pollen analysis, 4th ed. Chichester, John Wiley \& Sons. 328 p.

Froggatt, P. C. 1983: Toward a comprehensive Upper Quaternary tephra and ignimbrite stratigraphy of New Zealand using electron microprobe analysis of glass shards. Quaternary research 19: 188-200.

Froggatt, P. C.; Lowe, D. J. 1990: A review of late Quaternary silicic and some other tephra formations from New Zealand: their stratigraphy, nomenclature, distribution, volume, and age. New Zealand journal of geology and geophysics 33: 89-109.

Gibb, J. G. 1986: A New Zealand regional Holocene eustatic sea-level curve and its application to determination of vertical tectonic movements. Royal Society of New Zealand bulletin 24: 377-395.

Grimm, E. C. 1987: CONISS: a FORTRAN 77 program for stratigraphically constrained cluster analysis by the method of incremental sum of squares. Computers and geosciences 13: 13-35.

Gupta, S. K.; Polach, H. A. 1985: Radiocarbon dating procedures at ANU. Handbook, Radiocarbon Dating Laboratory. Canberra, Australian National University.

Hodder, A. P. W.; de Lange P. J.; Lowe, D. J. 1991: Dissolution and depletion of ferromagnesian minerals from Holocene tephra layers in an acid bog, New Zealand, and implications for tephra correlation. Journal of Quaternary science 6: 195-208.

Hogg, A. G.; Lowe, D. J.; Hendy, C. H. 1987: University of Waikato radiocarbon dates I. Radiocarbon 29: 263-301.

Hull, A. G. 1985: A possible sea level rise c. 4500 years B. P.: evidence from New Zealand coast. In: Pillans, B. J. ed. Proceedings of the second CLIMANZ conference. Geology Department, Victoria University of Wellington publication 31: 8-12.

Lowe, D. J. 1988a: Stratigraphy, age, composition, and correlation of late Quaternary tephras interbedded with organic sediments in Waikato lakes, North Island, New Zealand. New Zealand journal of geology and geophysics 3I: 125-165.

Lowe, D. J. 1988b: Late Quaternary volcanism in New Zealand: towards an integrated record using distal airfall tephras in lakes and bogs. Journal of Quaternary science 3: 11 1-120.

Lowe, D. J.; Hogg, A. G. 1986: Tephrostratigraphy and chronology of the Kaipo Lagoon, an 11,500 year-old montane peat bog in Urewera National Park, New Zealand. Journal of the Royal Society of New Zealand 16: 25-41.

Lowe, D. J.; Hogg, A. G. 1992: Application of new technology liquid scintillation spectrometry to radiocarbon dating of tephra deposits, New Zealand. Quaternary international 13/14: 135-142.

Lowe, D. J.; Wigley, G. N. A.; Dahm, J.; Nagatomo, Y. 1992: Late Quaternary tephrostratigraphy and Holocene dune development in the Papamoa-Te Puke area, Bay of Plenty. In: Rijske, W. C. comp. Field notes, 1992 Conference of the New Zealand Society of Soil Science, Rotorua: 36-41.

McGlone, M. S. 1981 : Forest fire following Holocene tephra fall. In: Howorth, R. et al. ed. Proceedings of tephra workshop. Geology Department, Victoria University of Wellington publication 20: 80-86.

McGlone, M. S. 1983: Holocene pollen diagrams, Lake Rotorua, North Island, New Zealand. Journal of the Royal Society of New Zealand 13:53-65.

McGlone, M. S. 1989: The Polynesian settlement of New Zealand in relation to environmental and biotic changes. New Zealand journal of ecology (supplement) 12: 115-129.

McGlone, M. S.; Anderson A. J.; Holdaway, R. N. 1994: An ecological approach to the Polynesian settlement of New Zealand. In: Sutton, D. G. ed. The origins of the first New Zealanders. Auckland, Auckland University Press: 136-163. 
Naish, T. R. 1990: Late Holocene mud sedimentation and diagenesis in the Firth of Thames: bentonite in the making. Unpublished M.Sc. thesis, lodged in the Library, University of Waikato, Hamilton.

Nairn, I. A.; Beanland, S.1989: Geological setting of the 1987 Edgecumbe earthquake, New Zealand. New Zealand journal of geology and geophysics 32: 1-13.

Newnham, R. M. 1990: Late Quaternary palynological investigations into the history of vegetation and climate in northern New Zealand. Unpublished Ph.D. thesis, lodged in the Library, University of Auckland, Auckland.

Newnham, R. M.; Lowe, D. J.; Green, J. D. 1989: Palynology, vegetation and climate of the Waikato lowlands, North Island, New Zealand, since c. 18,000 years ago. Journal of the Royal Society of New Zealand 19: 127-150.

Newnham, R. M.; de Lange, P. J.; Lowe, D. J. 1995. Holocene vegetation, climate and history of a raised-bog complex, northern New Zealand, based on palynology, plant macrofossils, and tephrochronology. The Holocene 5: 81-96.

Pullar, W. A. 1970: Soil survey of Kaituna swamp and environments. Kaituna Major Scheme, Lower Kaituna River, Volume 2: 1-19.

Pullar, W. A.; Patel, R. N. 1972: Identification of tree stumps and driftwood associated with tephra layers in alluvium, peat, and dune sands. New Zealand journal of botany 10: 605-614.

Pullar, W. A.; Selby, M. J. 1971: Coastal progradation of Rangitaiki Plains, New Zealand. New Zealand journal of science 14: 419-434.

Pullar, W. A.; Kohn, B. P.; Cox, J. E. 1977: Air-fall Kaharoa Ash and Taupo Pumice, and sea-rafted Loisels Pumice, Taupo Pumice, and Leigh Pumice in northern and eastern parts of the North Island, New Zealand. New Zealand journal of geology and geophysics 20: 697-717.

Quayle, A. M. 1984: The climate and weather of the Bay of Plenty region. New Zealand Meteorological Service miscellaneous publication 115 (1), 2nd. ed. $56 \mathrm{p}$.

Stokes, S.; Lowe, D. J.; Froggatt, P. C. 1992: Discriminant function analysis and correlation of late Quaternary rhyolitic tephra deposits from Taupo and Okataina volcanoes, New Zealand, using glass shard major element composition. Quaternary international 13/14: 103-117.

Wigley, G. N. A. 1990: Holocene tephrochronology and evolution of the Te Puke lowlands, Bay of Plenty, New Zealand. Unpublished M.Sc. thesis, lodged in the Library, University of Waikato, Hamilton.

Wilson, C. J. N. 1993: Stratigraphy, chronology, styles and dynamics of late Quaternary eruptions from Taupo volcano, New Zealand. Philosophical transactions of the Royal Society of London A343: 205-306.

Winkler, M. G. 1985: Charcoal analysis for palaeoenvironmental interpretation: a chemical assay. Quaternary research 23: 313-326

Woodroffe, C. D.; Curtis, R. J.; McLean, R. F. 1983: Development of a chenier plain, Firth of Thames, New Zealand. Marine geology 53: 1-22. 